\title{
Coconut water preservation and processing: a review
}

\author{
Alexia Prades ${ }^{1 *}$, Manuel Dornier ${ }^{1,2}$, Nafissatou DioP $^{3}$, Jean-Pierre PAIN ${ }^{4}$
}

${ }^{1}$ Cirad-Persyst, UMR 95 Qualisud, TA B-95 / 16, 73 rue Jean-François Breton, F-34398 Montpellier cedex 5, France, alexia.prades@cirad.fr

2 Montpellier SupAgro, UMR 95 Qualisud, TA B-95 / 16, 73 rue Jean-François Breton, F-34398 Montpellier Cedex 5, France,

manuel.dornier@cirad.fr

${ }^{3}$ Inst. Technol. Aliment. (ITA), route des Pères Maristes, BP 2765, Dakar, Sénégal, ndiop@ita.sn

${ }^{4}$ Univ. Montpellier II, UMR 95 Qualisud, Place Eugène Bataillon, F-34090 Montpellier, France,

jppain@polytech.univ-montp2.fr

\section{Coconut water preservation and processing: a review.}

Abstract - The product. Coconut water (Cocos nucifera L.) is an ancient tropical beverage whose original properties have drawn the attention of manufacturers as a natural functional drink. Preservation. This refreshing liquid comes mainly from immature coconuts which are difficult to collect, store and thus to commercialise. Nevertheless, some studies, mostly from Asian countries, tend to prove that the shelf life of immature coconut fruits could be prolonged thanks to post-harvest treatments. Processing. Coconut water itself, extracted from the nut, is obviously easier to handle but is also very sensitive to biological and chemical injuries. Thermal treatment combined with chemical additives are already used by the industry but other technologies such as micro- and ultrafiltration are not yet available on an industrial scale. Whatever the process, taste, aroma and colour (linked to enzymatic activities) are still difficult to control. Discussion. Results of former and recent investigations are discussed. Finally, suggestions are made for further research to increase our knowledge of this original tropical juice.

France / Cocos nucifera / coconuts / coconut water / plant developmental stages / maturation / quality / storage / preservation / keeping quality / processing
* Correspondence and reprints

Received 31 March 2011 Accepted 20 June 2011

Fruits, 2012, vol. 67, p. 157-171 (C) 2012 Cirad/EDP Sciences All rights reserved DOI: 10.1051/fruits/2012009 Www.fruits-journal.org

RESUMEN ESPAÑOL, p. 171

\section{Conservation et transformation de l'eau de noix de coco : une synthèse.}

Résumé - Le produit. L'eau de coco (Cocos nucifera L.) est un breuvage tropical dont les propriétés fonctionnelles naturelles intéressent aujourd'hui les industriels. Conservation. Ce liquide rafraîchissant provient des noix de coco immatures dont la récolte et le stockage restent délicats. Toutefois, certaines études menées essentiellement en Asie tendent à prouver que des traitements post-récoltes pourraient prolonger la durée de vie des noix immatures. Transformation. L'eau de coco extraite de la noix est évidemment plus simple à manipuler et transporter, mais sa composition la rend particulièrement sensible aux dégradations biologiques et chimiques. Des traitements thermiques combinés à l'usage d'additifs sont aujourd'hui utilisés dans l'industrie mais d'autres technologies comme la micro ou l'ultrafiltration ne sont toujours pas disponibles pour ce produit. Quel que soit le procédé de stabilisation utilisée, le goût et la flaveur originels de l'eau de coco restent très difficiles à préserver. Discussion. Dans cette synthèse, pour la première fois, les recherches sur l'eau de coco, des plus anciennes aux plus récentes, sont présentées; elles conduisent à proposer des pistes pour améliorer notre connaissance de ce jus de fruit tropical atypique.

France / Cocos nucifera / noix de coco / eau de coco / stade de développement végétal / maturation / qualité / stockage / préservation / aptitude à la conservation / traitement 


\section{Introduction}

Coconut (Cocos nucifera L.) is one of the most important and extensively grown palm trees worldwide. The inner part of the nut (endosperm) is divided into two edible parts: a white kernel and a clear liquid: coconut water [1]. Both parts can be processed in many different ways and lead to various products such as copra, virgin coconut oil, coconut cream, coconut milk, desiccated coconut, coconut water, nata de coco, etc. [2]. The market for canned coconut milk, coconut cream and coconut juice/ water is increasing considerably [3-5]. Coconut is no longer only an international oil commodity but is becoming a valuable fresh fruit.

Coconut water (CW), also called coconut juice (not to be confused with coconut milk), is a sweet refreshing drink taken directly from the inner part of coconut fruits [6]. It differs from coconut milk, which is the oily white liquid extracted from the grated fresh kernel. The coconut water consumed as a beverage usually comes from immature coconut fruits [7]. Due to its unique characteristics, coconut water is considered as a natural functional drink [8]. Its sugar content and mineral composition make it an ideal rehydrating and refreshing drink after physical exercise [9]. Previously considered as a simple tropical refreshment or occasionally as a medicine, coconut water is progressively becoming a natural healthy drink. As a beverage being extracted in few tropical and subtropical areas and only processed in some Brazilian or Asian industrial manufacturing plants, coconut water remains a traditional and under-used resource. In most cases, coconut water comes from small and scarce coconut tree plantations more related to "gardens", except in Brazil where the growing market demand led growers to create, a few years ago, large commercial coconut plantations. An increasing international demand for this product could be a highly positive issue for thousands of African and Asian small farmers. However, to compete on the international beverage market, Coco- nut water still has to be carefully processed, packed, transported and stored.

After suitable varieties have been identified, coconut palms have to be harvested at the right stage of maturity and in optimal conditions [10]. The immature fruits are often consumed immediately after harvest or sold, either on a local market ( $75 \%$ of the production) or dispatched, with or without pre-treatment, to the international market. Most whole young tender coconuts from the Asian and Pacific Coconut Community pass through Hong Kong or Singapore markets before being transported by plane to Taiwan, the US or the EU. However, a tender coconut can be heavy [(0.8 to 2$) \mathrm{kg}]$, leading to considerable air freight costs.

Apart from the market for whole young tender coconuts, whose transport can be expensive, thus limiting exports, coconut water is also removed from the nut and processed. Although coconut water is sterile as long as it remains in the inner cavity of the nut [11], it is very difficult to preserve. As soon as the nut is opened, its biochemical composition and physical appearance change. Thermal and non-thermal treatments, sometimes combined with additives, have been tried with varying degrees of success. In Asian countries and in Brazil, canned, bottled or tetra-packed coconut water is available. But those who have tasted these manufactured juices are aware that they differ from fresh coconut juice. Prolonging the coconut water shelf life without modifying its flavour and nutritious properties remains a technical challenge. Fermentation processes are also encountered but lead to fully different final products which do not resemble natural coconut water. We drew a flow diagram of the different manufactured products made of young coconut water (figure 1).

Current research on the post-harvest sector of coconut water is rare. Two different fields have to be taken into account: preservation of the whole nut (the Young Tender Coconut, YTC market) and processing of coconut water. Nevertheless, we found in the literature these two approaches that we describe in detail in our review. 


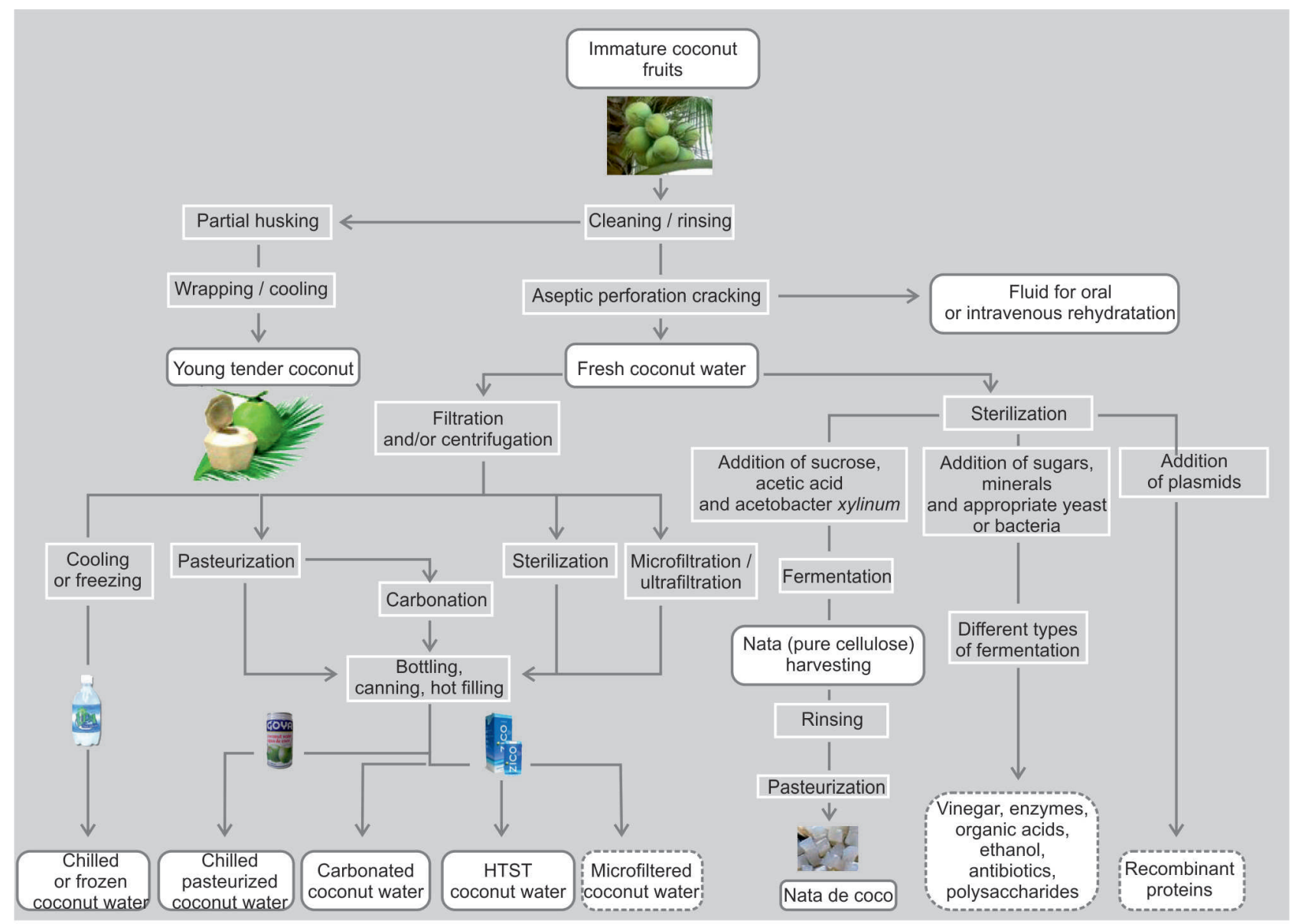

\section{Preservation and sale of young tender coconuts}

Young tender coconuts are still the best way to preserve coconut water (inside its natural container) but the nuts cannot be stored for more than 6 days at ambient temperature [12]. In Sri Lanka, the Coconut Research Institute suggested some technical guidelines for the shipping of King Coconuts for export [13]. Following their advice on preparation, young tender coconuts can remain fresh and safe for 3 weeks at (13 to 15$){ }^{\circ} \mathrm{C}$ and $70 \% \mathrm{RH}$ (reefer containers). Similarly, a project funded by the Indian Coconut Development Board has provided a complete supply chain for young tender Coconuts from the field to the kiosks and retailers. The minimum processing consists of dipping partially husked nuts in a solution of $0.5 \%$ citric acid and $0.5 \%$ of potassium metabisulphite for $3 \mathrm{~min}$. The final product, wrapped with polypropylene cling film, can be stored for up to 24 days at ( 5 to 7$){ }^{\circ} \mathrm{C}$ [14].

As for many tropical fruits, reducing the temperature below $12{ }^{\circ} \mathrm{C}$ results in chilling injury: the coconut skin rapidly browns. For the whole nut without any treatment, preservation for 28 days at either $12^{\circ} \mathrm{C}$ or $17^{\circ} \mathrm{C}$ gave the best results reported in the literature [15-17]. For the whole nut with treatment such as sanitisation, i.e., immersion in a specific solution for a few minutes [18], the best result was obtained after 21 days at $12{ }^{\circ} \mathrm{C}$ [19]. Surprisingly, sanitisation did not improve the shelf life of the nut. For the whole nut with film wrapping, results were equivalent or even better: 28 days at $12{ }^{\circ} \mathrm{C}$ with PE film [16] and 30 days at $12{ }^{\circ} \mathrm{C}$ with PVC film [19]. The longest shelf life for

\section{Figure 1.}

Flow diagram of the different methods of processing young coconut fruit. 
whole young tender coconuts was obtained with paraffin wrapping stored for 49 days at $12{ }^{\circ} \mathrm{C}[17]$.

The most common method to promote the sale of young tender coconuts on local markets, in supermarkets, or in restaurants is to partially remove the tender mesocarp (husk) up to the outer shell. The partially husked young tender coconuts have become so famous on Asian markets, especially in Thailand, that a prototype machine has been designed to trim and open young coconut fruits [20, 21].

However, the exposed trimmed husk quickly turns brown, reducing the commercial value of the fruit even though the coconut water remains of good quality inside. Without any packing or sanitisation, these partially husked nuts can only be stored for 7 days at $17^{\circ} \mathrm{C}$. To overcome the problem, the freshly-cut nut can be immersed in a solution of anti-browning agent such as sodium metabisulphite at a concentration of about $2 \mathrm{~g} \cdot \mathrm{L}^{-1}$ for (5 to 10 ) $\mathrm{min}$ [22]. With anti-browning treatment and a film wrapping, the shelf life is estimated at 24 days at $5{ }^{\circ} \mathrm{C}$ [23]. Finally, immersion in carnauba wax emulsion maintains the freshness of partially husked young tender coconuts for up to 30 days at $12{ }^{\circ} \mathrm{C}$ [24].

In conclusion, the best method for prolonging shelf life was obtained using wax coatings: paraffin for whole young tender coconuts for up to 49 days at $12{ }^{\circ} \mathrm{C}$, and carnauba for partially husked fruits for up to 30 days at $12{ }^{\circ} \mathrm{C}$. Other waxes should be tested to preserve young tender coconuts and to optimise conditions for the sale of this natural product. Additional work is also needed to optimise coatings and packaging. A better understanding of the coconut fruit ripening process and senescence could also help design suitable storage conditions such as modified atmosphere packaging (MAP).

\section{Coconut water processing}

\subsection{Mature coconut water processing}

As early as 1977 , Sison raised the question of the disposal of the mature coconut water
[25]. Until now mature coconut water has been considered as waste, especially in coconut processing plants (desiccated coconut factories, coconut milk factories, etc.). Pramith estimated the total volume of Coconut water discarded by the Sri Lankan coconut mills at $261 \mathrm{Mt}$ per year [26]. The liquid causes environmental pollution and is also a waste of a valuable food [27].

\subsubsection{An environmental problem}

A desiccated coconut factory which splits about 300,000 coconuts a day throws out approximately $5.3 \mathrm{~m}^{3}$ of pure coconut water plus $44 \mathrm{~m}^{3}$ of wash water, giving a total of $50 \mathrm{~m}^{3}$ of effluent per day. Pure coconut water has a BOD (Biological Oxygen Demand) of $29,000 \mathrm{mg} \cdot \mathrm{L}^{-1}$ and wash water about $3,000 \mathrm{mg} \cdot \mathrm{L}^{-1}$ so that the global liquid waste from the factory has about $5,800 \mathrm{mg} \cdot \mathrm{L}^{-1}$ of BOD, which has to be reduced to the accepted level of $50 \mathrm{mg} \cdot \mathrm{L}^{-1}$ [25]. Several conventional techniques can be used in Sri Lankan conditions including letting the coconut water settle and skimming off the surface oily layer, which can be processed into soap. Anaerobic treatment in an Upflow Anaerobic Sludge Blanket (UASB) and aerobic treatment in ponds have also been suggested [27]. The quality of the effluent to discharge into inland surface waters includes a $\mathrm{pH}$ of 6.5 to 8 and maximum allowed amount of $300 \mathrm{mg} \cdot \mathrm{L}^{-1}, \quad 30 \mathrm{mg} \cdot \mathrm{L}^{-1}$ and $10 \mathrm{mg} \cdot \mathrm{L}^{-1}$ for COD (Chemical Oxygen Demand), BOD and oil, respectively [28].

\subsubsection{A valuable food}

First attempts to make use of the liquid waste as food failed due to technical difficulties involved in removing the residual oil from the liquid. A membrane was tested to separate the residual oil. The mature coconut water was previously heated to $95^{\circ} \mathrm{C}$ to precipitate the protein. Then pasteurisation gave a relatively high flux of up to $42 \mathrm{~L} \cdot \mathrm{h}^{-1} \cdot \mathrm{m}^{-2}$ at $60{ }^{\circ} \mathrm{C}$ and up to $245 \mathrm{kPa}$ with a $0.45-\mu \mathrm{m}$ hydrophilic PVDF membrane [26]. Fresh mature coconut water was also concentrated by plate-and-frame reverse osmosis using composite membranes (DDS type HR98 with a cut-off of less than $500 \mathrm{Da})$ at (2, 3 and 4) $\mathrm{MPa}$ inlet pressures [29]. 
The most economical and practical ways to enhance the value of coconut water are still making vinegar [30], using it as a growth medium for yeasts [25], for xanthan gum production [31], for the culture for various lactic acid bacteria [32] or for Nata de coco production [33]. Nata de coco is pure cellulose, free of lignin and hemicellulose, produced by Acetobacter xylinum [34-36]. Besides its use as a food, the gel-like substance is also considered to impart extraordinary mechanical strength when processed into film or sheets $[37,38]$. Nata de coco was also tested as a natural coating for minimally processed fruits [39]. Coatings containing 1\% and $2 \%$ of carboxymethyl cellulose from Nata de coco, referred to as carboxymethylnata, were applied to bell peppers to evaluate the effect of the polysaccharide coating on the post-harvest life of the fruits. The results suggested that this coating significantly reduced the ripening rate. Jagannath et al. studied the production of Nata de coco by Acetobacter xylinum using tender coconut water as a medium instead of the usual mature coconut water [40].

\subsection{Young coconut water processing}

Although some publications addressed the processing of young coconut water before the mid-1990s [41-43], the first paper presenting detailed scientific results of thermal treatment of young coconut water was published in 1996. Since then, ten articles have been published on pasteurisation and two on sterilisation. Two additional publications by the University of Sao Paulo, Brazil, described microwave treatment of coconut water. Besides conventional thermal techniques, cooling and freezing are the two processes currently used in the industry. Surprisingly, they are only cited or described in three articles and one manual. As far as we know, membrane filtration techniques, mentioned in seven papers, have not yet been used industrially for young coconut water.

No information was found in the literature on young coconut water aseptic extraction, whereas it is the first crucial operation in coconut water processing. It is probably due to the fact that this opening step is the key issue to obtain a high-quality raw material and each company wants to preserve its know-how. Another explanation could be that it is still a highly challenging technical problem because of the rapid discoloration and fermentation occurring just after the coconut cracking.

\subsubsection{Thermal treatments}

\subsubsection{Pasteurisation, sterilisation and combined treatments}

The first paper on the preservation of tender coconut water was Indian [43]. Additives such as nisin, minimum heating, and packing in polymeric pouches and metal cans were cited as being used to achieve commercial sterility. A more detailed process to develop shelf-stable ready-to-serve green coconut water was described by Chowdhury et al. [44]. The authors filtered the freshly extracted coconut water, pasteurised it at $85^{\circ} \mathrm{C}$ for $10 \mathrm{~min}$ and cooled it. The coconut water was then poured into metal cans or glass bottles. Cans and bottles were sterilised at $121{ }^{\circ} \mathrm{C}$ for $30 \mathrm{~min}$ and at $100{ }^{\circ} \mathrm{C}$ for $15 \mathrm{~min}$, respectively.

An experimental hot-fill process was also compared with other commercial coconut water subjected to cooling, freezing, aseptic filling of cartons and industrialised hot-fill processing [45]. The experimental process consisted of filtration, addition of citric acid to reduce the $\mathrm{pH}$ to 4.5 , addition of fructose to standardise the soluble solids content at $70 \mathrm{~g} \cdot \mathrm{L}^{-1}$ and sodium metabisulphite $\left(0.45 \mathrm{~g} \cdot \mathrm{L}^{-1}\right)$, addition of sodium benzoate $\left(1.24 \mathrm{~g} \cdot \mathrm{L}^{-1}\right)$ and ascorbic acid $\left(0.0013 \mathrm{~g} \cdot \mathrm{L}^{-1}\right)$, pasteurisation at $90{ }^{\circ} \mathrm{C}$ for $2 \mathrm{~min}$ and pouring into 200-mL glass bottles. Samples were stored at ambient temperature $\left(28^{\circ} \mathrm{C}\right)$. The experimental hot-fill samples were acceptable even though they did not resemble other commercial samples in terms of physicochemical attributes.

In Taiwan, sterilisation is commonly used as a thermal treatment to stabilise coconut water and frequently causes non-enzymatic browning of the liquid [46]. In order to remove the brown colour, active carbon, cation exchange resin, sulphur compounds 
such as sulphite, acetyl-cysteine, glutathione and cysteine were successfully tested.

\subsubsection{Thermal treatment and microbiological effects}

The main objective of the thermal treatments is to stop or eradicate the microbiological load for consumer safety [47]. Thermal treatments were applied to buko, a mix of coconut water/distilled water (80/20) and, respectively, (60 and 20) $\mathrm{g}$ of macerated solid endosperm and refined sugar per litre of beverage. Glass test tubes were immersed in a hot water bath at $(60,70 \text { and } 80)^{\circ} \mathrm{C}$ for different lengths of time. According to the different temperatures and time treatments, a $D$ value was determined, i.e. the time (in minutes) required for a $1 \log _{10}$ reduction of the survival of the reference strain. The calculated $D$ values for Escherichia coli on buko ranged from $(0.26 \pm 0.01) \mathrm{min}$ at $80^{\circ} \mathrm{C}$ to $(0.56 \pm 0.08) \min$ at $60{ }^{\circ} \mathrm{C}$.

\subsubsection{Thermal treatment and thermophysical properties}

Before the design or adaptation of specific food processing equipment, an important step is often left out: assessment of the effect of temperature on the thermophysical properties of the raw material. Food composition and temperature are important factors which affect the thermal behaviour of a tropical fluid such as coconut water. The density, dynamic viscosity, thermal diffusivity, thermal conductivity and specific heat of the water of green Babia coconuts (presumed to be the Brazilian Green Tall or Dwarf variety) bought from a local market in Brazil were measured using a range of temperatures from $5^{\circ} \mathrm{C}$ to $80^{\circ} \mathrm{C}$ [48]. Temperature significantly affected the above properties, which displayed linear trends, except for dynamic viscosity, which displayed an exponential curve. Different equations and models were proposed to fit the experimental data (table I).

\subsubsection{Thermal treatment and enzymatic browning control}

The major problem encountered in coconut water stabilisation is apparently not microbiological or chemical stability, since these objectives have already been partially achieved [44, 45], but the fact that enzymes need to be inactivated to stabilise the colour and taste of the final product. As is true for many fruit juices, polyphenol oxydase (PPO) and peroxydase (POD) enzymes are present in young coconut water.

The consequence of PPO or POD activities in coconut water is discoloration. Yellow, brown or pink discoloration of the coconut water can occur a few minutes or a few hours after the nut is cracked. Discoloration can also occur after several weeks of storage of processed coconut water. Even though the mechanisms of PPO and POD activities are well described from a biochemical point of view [49], the same mechanisms remain to be explained during ripening of the fruit and post-harvest. A range of different factors affect the levels of activities of the enzymes and are often difficult to control (temperature, $\mathrm{pH}$, mechanical impacts, oxygen concentration, etc.). To prevent the consequences of PPO and POD activities in coconut water, several authors suggested inactivating the enzymes by thermal treatments either using conventional methods (pasteurisation, sterilisation) or by microwave heating.

At a low temperature $\left(90^{\circ} \mathrm{C}\right)$, total inactivation was obtained after $550 \mathrm{~s}$ for PPO and after $310 \mathrm{~s}$ for POD [50]. At a temperature of $139{ }^{\circ} \mathrm{C}$ for $10 \mathrm{~s}$ combined with $200 \mathrm{mg} \cdot \mathrm{L}^{-1}$ of ascorbic acid, PPO was entirely inactivated, whereas POD was still active at $40 \%$ of its original level [51]. Contrary to Campos et al., who underlined the fact that PPO was more resistant than POD to pasteurisation [50], Abreu and Faria concluded that POD was inversely more thermostable using sterilisation [51]. At temperatures below $90^{\circ} \mathrm{C}$, the POD of the coconut water is less thermostable than PPO, like strawberry [52], but unlike apple [53] or pineapple [54].

Other investigations of the kinetics of inactivation of the two enzymes indicated that the situation is more complex $[55,56]$. In fact, two isoenzymes for PPO and POD are present in young coconut water. The thermal behaviour of the different fractions was analysed and quantified during pasteurisation. Two different mathematical 
Table I.

Experimental values of thermophysical properties of coconut water and equations for their prediction (adapted from Fontan et al. [48]).

\begin{tabular}{lccccc}
$\begin{array}{l}\text { Temperature } \\
\left({ }^{\circ} \mathrm{C}\right)\end{array}$ & $\begin{array}{c}\text { Density } \\
(\rho)\end{array}$ & $\begin{array}{c}\text { Thermal diffusivity } \\
(\alpha)\end{array}$ & $\begin{array}{c}\text { Dynamic viscosity } \\
(\mu)\end{array}$ & $\begin{array}{c}\text { Specific heat } \\
\left(\mathrm{c}_{\mathrm{p}}\right)\end{array}$ & $\begin{array}{c}\text { Thermal conductivity } \\
(\mathrm{K})\end{array}$ \\
\hline 5 & $\left(\mathrm{~kg} \cdot \mathrm{m}^{-3}\right)$ & $\left(10^{-7} \mathrm{~m}^{2} \cdot \mathrm{s}^{-1}\right)$ & $\left(10^{-3} \mathrm{~Pa} \cdot \mathrm{s}\right)$ & $\left(\mathrm{J} \cdot \mathrm{kg}^{-1} \cdot{ }^{\circ} \mathrm{C}^{-1}\right)$ & $\left(\mathrm{W} \cdot \mathrm{m}^{-1} \cdot{ }^{\circ} \mathrm{C}^{-1}\right)$ \\
20 & 1021.72 & 1.36 & 1.54 & 4056.5 & 0.56 \\
35 & 1016.75 & 1.39 & 1.00 & 4056.5 & 0.57 \\
50 & 1011.33 & 1.46 & 0.69 & 4056.5 & 0.60 \\
65 & 1007.12 & 1.50 & 0.45 & 4056.5 & 0.61 \\
80 & 1000.03 & 1.55 & 0.43 & 4056.5 & 0.63 \\
\end{tabular}

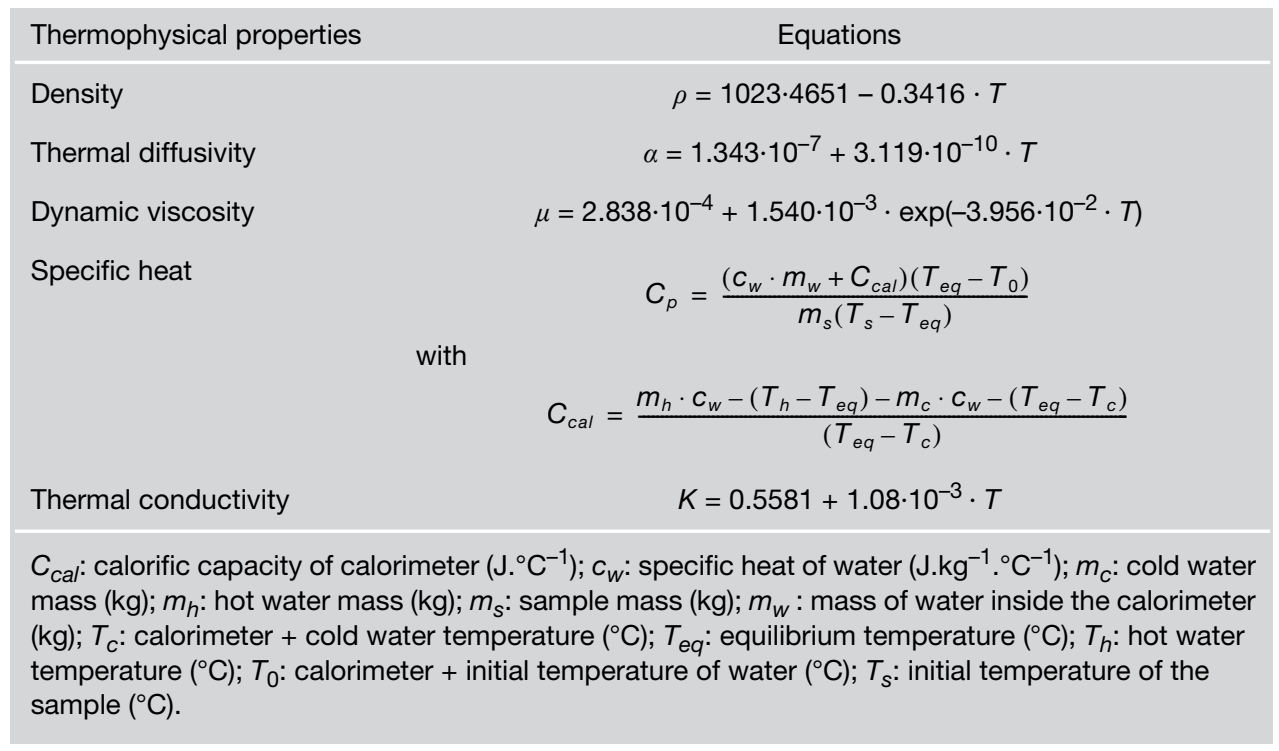

equations were developed to predict the thermal resistance of PPO and POD fractions using the same type of multicomponent first-order model (table II).

The thermal resistance of POD can be estimated by a $D$ value, i.e., the time required to reduce the enzyme activity to $10 \%$ of its initial value. The temperature required for a $D$ value of $5 \mathrm{~min}$, which was $81.2{ }^{\circ} \mathrm{C}$ for coconut water POD [57], was shown to be higher than the $44.5^{\circ} \mathrm{C}$ required for pepper [58], $75^{\circ} \mathrm{C}$ for grape [59] and $80.3{ }^{\circ} \mathrm{C}$ for carrot [60], but slightly lower than the $83.2^{\circ} \mathrm{C}$ for potato [60].

Apart from classical thermal treatments, an unconventional technique, microwave heating, has been used to inactivate PPO and POD enzymes [57, 61]. First, the thermal behaviour of solutions simulating the chemical constituents of coconut water (PPO/ water, $\mathrm{PPO} /$ sugars, $\mathrm{PPO} /$ salts and $\mathrm{PPO} /$ sugars/salts, and equivalent for POD) was 


\section{A. Prades et al.}

Table II.

Mathematical models of polyphenoloxydase (PPO) and peroxydase (POD) thermal inactivation in coconut water.

\begin{tabular}{lcccccccc} 
Enzyme & $\begin{array}{c}\text { Enzymatic activity } \\
\left(\mathrm{U} \cdot \mathrm{mL}^{-1} \cdot \mathrm{min}^{-1}\right)\end{array}$ & $\begin{array}{c}T \\
\left({ }^{\circ} \mathrm{C}\right)\end{array}$ & $\begin{array}{c}\text { Model } \\
{[55]}\end{array}$ & \multicolumn{3}{c}{ Coefficient of multicomponent first-order model } \\
& & & $\alpha$ & $k_{1}\left(\mathrm{~s}^{-1}\right)$ & $k_{2}\left(\mathrm{~s}^{-1}\right)$ & $R^{2}$ \\
PPO & 16.5 & 80 & $\frac{A}{A_{0}}=\alpha \cdot e^{\left(-k_{1} t\right)}+(1-\alpha) \cdot e^{\left(-k_{2} t\right)}$ & 0.6559 & $1.70 \mathrm{E}-03$ & $1.98 \mathrm{E}-03$ & 0.938 \\
POD & 3.6 & 80 & 0.5826 & $2.19 \mathrm{E}-02$ & $-7.12 \mathrm{E}-04$ & 0.893 \\
& & 85 & 0.2068 & $1.28 \mathrm{E}+00$ & $3.01 \mathrm{E}-03$ & 0.953 \\
& & 90 & 0.5983 & $2.36 \mathrm{E}-02$ & $2.39 \mathrm{E}-02$ & 0.970
\end{tabular}

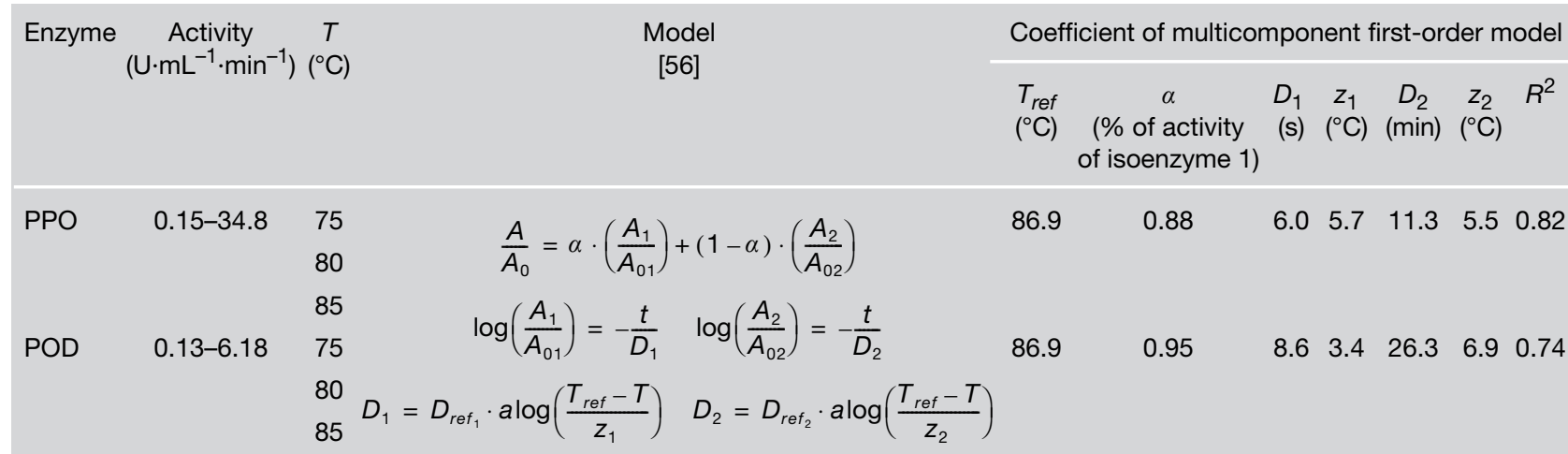

A: enzymatic activity $\left(\mathrm{U} \cdot \mathrm{mL}^{-1} \cdot \mathrm{min}^{-1}\right) ; A_{0}$ : initial enzymatic activity $\left(\mathrm{U} \cdot \mathrm{mL}^{-1} \cdot \mathrm{min}^{-1}\right) ; \alpha$ : fraction of the initial activity of the isoenzyme 1 (\%); $t$ : time (s); $T_{\text {ref: }}$ reference temperature $\left({ }^{\circ} \mathrm{C}\right) ; D$ : decimal reduction time (min); $z$ : temperature increase that reduces $D$-value by $90 \%$.

characterised. The influence of sugars and salts on enzyme activity was demonstrated. Sugars, especially fructose, were more detrimental to POD than to PPO inactivation. Salts significantly affected PPO and POD stability. At temperatures above $77^{\circ} \mathrm{C}$, PPO was found to be more thermally resistant to microwave heating than POD, corroborating the results of Campos et al. [50]. The presence of salts in the simulated solutions combined with microwave heating reduced both enzymatic activities to undetectable levels. In addition, the thermal behaviour of natural coconut water was compared with that of the simulated solutions [57]. It appeared that natural enzymes were more thermo-resistant than commercial ones. The authors used a first-order kinetic model to describe the experimental results and determined $D$ parameters for $\mathrm{PPO}, \mathrm{D}_{92.20{ }^{\circ} \mathrm{C}}=$ $52 \mathrm{~s}$, and for POD, $\mathrm{D}_{92.20^{\circ} \mathrm{C}}=16 \mathrm{~s}$. The thermal inactivation of both enzymes was faster with microwave processing than with conventional pasteurisation.

\subsubsection{A simple thermal treatment: refrigeration}

Cold preservation of young coconut water has been studied by the FAO for a few years with the aim of extending the shelf life of this fragile product. A manual entitled "Good practice for the small-scale production of bottled coconut water" [62] was designed for use as a learning resource for small and micro-entrepreneurs as well as a training resource for extension workers and trainers. The manual describes methods for harvest, storage conditions and sanitisation of the coconut fruits. It then explains how to extract, filter on cheesecloth, pour into bottles and store the coconut water at $4{ }^{\circ} \mathrm{C}$. No peer-reviewed article was found on international databases on 


\begin{tabular}{|c|c|c|c|c|c|c|c|c|c|}
\hline Treatment & $\begin{array}{l}\text { Membrane } \\
\text { porosity } \\
(\mu \mathrm{m})\end{array}$ & $\begin{array}{l}\text { Membrane } \\
\text { molecular } \\
\text { cut-off } \\
(\mathrm{kDa})\end{array}$ & $\begin{array}{l}\text { Surface } \\
\qquad\left(\mathrm{m}^{2}\right)\end{array}$ & Membrane & $\begin{array}{c}\text { Temperature } \mathrm{T} \\
\left({ }^{\circ} \mathrm{C}\right)\end{array}$ & $\begin{array}{c}\text { Transmembrane } \\
\text { Pressure } \\
(\mathrm{kPa})\end{array}$ & $\begin{array}{l}\text { Filtration } \\
\text { type }\end{array}$ & $\begin{array}{l}\text { Permeate } \\
\quad \text { flux } \\
\left(\mathrm{L} \cdot \mathrm{h}^{-1} \cdot \mathrm{m}^{-2}\right)\end{array}$ & References \\
\hline \multirow[t]{4}{*}{$\begin{array}{l}\text { Microfiltration } \\
\text { (MF) }\end{array}$} & 0.2 & - & $\begin{array}{c}\text { Not } \\
\text { available }\end{array}$ & Not available & 6 & Not available & $\begin{array}{c}\text { Not } \\
\text { available }\end{array}$ & $\begin{array}{c}\text { Not } \\
\text { available }\end{array}$ & [64] \\
\hline & 0.1 & - & 0.72 & $\begin{array}{l}\text { Plate and frame } \\
\text { polysulphone }\end{array}$ & 25 & 200 & Dead-end & 20 & {$[75]$} \\
\hline & 0.2 & - & 0.22 & Tubular ceramic & $20-25$ & $140-158$ & $\begin{array}{l}\text { Cross Flow } \\
7 \mathrm{~m} \cdot \mathrm{s}^{-1}\end{array}$ & 150 & {$[65]$} \\
\hline & 0.2 & - & 0.013 & $\begin{array}{l}\text { Plate and frame } \\
\text { cellulose nitrate }\end{array}$ & 20 & 16 & Dead-end & $\begin{array}{c}\text { Not } \\
\text { available }\end{array}$ & {$[76,77]$} \\
\hline \multirow[t]{4}{*}{$\begin{array}{l}\text { Ultrafiltration } \\
\text { (UF) }\end{array}$} & $\begin{array}{c}0.1 \\
0.025\end{array}$ & - & $\begin{array}{c}\text { Not } \\
\text { available }\end{array}$ & $\begin{array}{l}\text { Plate and frame } \\
\text { cellulose ester }\end{array}$ & Not available & Not available & Dead-end & $\begin{array}{c}\text { Not } \\
\text { available }\end{array}$ & {$[78]$} \\
\hline & - & $10,30,50$ & 0.09 & $\begin{array}{l}\text { Plate and frame } \\
\text { regenerated } \\
\text { cellulose }(10 \mathrm{kDA}) \\
\text { and } \\
\text { polyethersulphone } \\
\text { (30 and } 50 \mathrm{kDa})\end{array}$ & 25 & 60 & Dead-end & $\begin{array}{c}\text { Not } \\
\text { available }\end{array}$ & [65] \\
\hline & - & $20,50,100$ & 0.72 & $\begin{array}{l}\text { Plate and frame } \\
\text { polysulphone }\end{array}$ & 25 & 200 & Dead-end & 5 & {$[75]$} \\
\hline & - & 50 & 0.0035 & $\begin{array}{l}\text { Plate and frame thin } \\
\text { film composite } \\
\text { polyamide }\end{array}$ & $\begin{array}{c}\text { Ambient } \\
\text { temperature }\end{array}$ & $276-690$ & $\begin{array}{l}\text { Stirred cell } \\
800- \\
1600 \mathrm{rpm}\end{array}$ & $25-130$ & [66] \\
\hline
\end{tabular}

this popular and frequently-used procedure for the preservation of coconut water.

\subsubsection{Non-thermal treatments}

Non-thermal treatments such as membrane filtration are interesting alternatives to stabilise delicate aromatic fruit juices. The original flavour of coconut water is sensitive to temperature and microfiltration (MF) could help to pasteurise the product at ambient temperature while preserving its aroma. Moreover, ultrafiltration (UF) is used for the extraction of small molecules from a solution and enzymes, such as PPO and POD, are small molecules of, respectively, $73.8 \mathrm{kDa}$ and $49.2 \mathrm{kDa}$ [63].

Several authors tried to stabilise coconut water using either MF or UF (table III). The FAO has also taken out a patent [64] claiming that high-speed centrifugation followed by microfiltration and aseptic packaging can preserve young coconut water for a period of at least 6 months.

Working on a semi-industrial microfiltration unit, Diop observed relatively high steady-state flux at $150 \mathrm{~L} \cdot \mathrm{h}^{-1} \cdot \mathrm{m}^{-2}$ and a loss of only 3\% of coconut water at a VRF (Volumic Reduction Factor) of 25 [65].

To prevent enzymatic discoloration, a few authors tried to use ultrafiltration immediately after microfiltration to remove PPO and POD from the coconut water. Ultrafiltration retained $92 \%$ and $91 \%$ of PPO and POD activity thanks to a $10 \mathrm{kDa}$ cut-off membrane [65]. In all cases, PPO activity was considerably reduced and POD activity was undetectable. Equations were developed for ultrafiltration to estimate and predict its performance [66].

Another way to cope with coconut water pinking is to mix it with a coloured fruit juice such as cashew apple juice [67-69], acerola 
[70] or maracuja [71]. The association of the two fruit juices combines their sensory and nutritional properties, while cumulating their respective advantages.

Other investigations tried to prevent "pinking" of coconut water by using different types of food-grade resins: polyvinylpolypyrrolidone (PVPP), calcium bentonite and gelatin [72], as commonly used in wine and beer processing. None of the tested resins was successful in controlling discoloration but further investigations are required to improve the experimental methodology. Continuous dense-phase $\mathrm{CO}_{2}$ (DPCD), a very recent technology, also failed to prevent discoloration at ambient temperature [73].

Hence, from a microbiological point of view, microfiltration appears to be a satisfactory way to stabilise coconut water but has no effect on enzyme activity since the enzymes cross the membrane. Ultrafiltration retains PPO and POD enzymes. The discoloration of coconut water is still not completely elucidated. Thus, emerging technologies such as high-pressure, pulsed electric field or ohmic heating should be investigated.

\subsubsection{Shelf life and quality of processed young coconut water}

Few studies have dealt with the quality and shelf life of processed coconut water. Concerning shelf life, it is clear that neither classical thermal pasteurisation, nor sterilisation, nor microfiltration were sufficient to obtain a shelf-stable product without additives. Efficient results were obtained by adding molecules such as nisin [43], ascorbic acid [50] or citric acid and sodium metabisulphite [74]. In these cases only, it was possible to preserve pasteurised coconut water for 2 to 3 months at ambient temperature or refrigerated. Sterilisation prolonged the shelf life of coconut water to 10 months at ambient temperature and to 12 months at $4{ }^{\circ} \mathrm{C}$ [44]. The storage stability of the canned and bottled green coconut water was satisfactory but the addition of citric acid did change the taste of the processed product.

Microfiltration did not significantly influence $\mathrm{pH}$, acidity, total soluble solids or total solids of clarified coconut water but increased clarity (measured as luminance $L$ with a Hunter-Lab system), decreased turbidity and protein content by $24 \%$ [75]. With different equipment and membranes, a similar increase in clarity, and a decrease of $13 \%$ in protein content and turbidity were also observed in clarified coconut water [76, 77]. Furthermore, microfiltration caused a significant decrease in the ash content of the permeate. $\mathrm{K}, \mathrm{Mg}, \mathrm{Ca}, \mathrm{Fe}$ and $\mathrm{Cu}$ concentrations decreased by, respectively, (10, 16, 19, 20 and 22$) \%$. Only calcium concentrations remained stable. Physical properties such as surface tension and viscosity changed, whereas the specific gravity was not affected $[76,77]$.

Microfiltration obviously did not stop the pink coloration of the clarified coconut water. The pink coloration occurred in microfiltered coconut water from Dwarf varieties but not from Tall varieties when stored at ambient temperature. When stored at $9{ }^{\circ} \mathrm{C}$ to $10^{\circ} \mathrm{C}$ just after processing, discoloration did not occur in any of the samples. However, the samples from Dwarf varieties still became pink when placed at ambient temperature after cold storage [64, 65].

Finally, the taste of the microfiltered coconut water was found to be very similar to that of fresh coconut water but the aroma was lost during processing, even though the overall acceptability of the final product by a panel of consumers was good [76, 77].

Ultrafiltration retained $\mathrm{PPO}$ and POD enzymes. Retention percentages of protein of, respectively, (25, 38 and 43)\% for the (100, 50 and 20) kDa cut-off membranes were confirmed $[66,75]$. The assessment of the effect of three different processes (ultrafiltration, pasteurisation and freezing) on the mineral composition of young coconut water showed that the ultrafiltration membrane retained most of the minerals present in coconut water. In contrast, pasteurisation tended to increase $\mathrm{Cu}, \mathrm{Fe}$ and $\mathrm{Zn}$ concentrations, whereas freezing completely changed the mineral distribution [78]. Ultrafiltration was able to retain PPO and POD enzymes but also retained minerals, and these are major quality criteria and a strong marketing argument for the young coconut water beverage. 
As the market for processed coconut water is constantly growing in Brazil, Luvielmo et al. performed a quantitative descriptive analysis of Brazilian branded coconut waters to compare the effects of different types of processing: freezing, pasteurisation and microwave heating [79]. Contrary to microwave-heated samples, the frozen coconut water samples showed the best values for typical characteristics of green coconut water. This is the first time a list of twelve descriptors has been drawn up for green coconut water by an expert jury. Unfortunately, this study was performed using commercialised samples of different origin and without a reference sample (i.e., fresh coconut water without treatment). Four other articles compared, respectively, 9, 3, 3 and 26 different coconut water brands sold in Brazilian supermarkets. Marked variability of the analysed samples was observed: De Sousa et al. in mineral composition [80], Abreu et al. in organoleptic quality [81], and Pinheiro et al. and Fortes et al. in physicochemical and organoleptic characteristics [82, 83]. This variability was nevertheless in accordance with the Brazilian standard. On the other hand, 100\% of the analysed samples were microbiologically contaminated beyond legal limits.

Nunes et al. studied the hygienic conditions and characteristics of commercial foods marketed in Brazil and especially fruit juices [84]. They confirmed the previous results of Fortes et al. regarding the bad hygienic conditions during processing and handling of young coconut fruits [83]. They also confirmed the results of an investigation by Walter et al., who demonstrated that Listeria monocytogenes was a possible contaminant of young coconut water and grew easily on this media even at $4{ }^{\circ} \mathrm{C}$ [85]. Therefore, better care needs to be paid to packaging [86] and storage [87], training of the processors and vendors and adequate management of wastes during fruit juice processing.

Attention also needs to be paid to controlling the physicochemical and microbiological quality of young coconut product sold. As far as we know, only Brazil [83] and India [88] already have or will soon have official standards for processed young coconut water.

\section{Conclusion and future prospects}

Coconut water is not a common fruit juice and thus not easy to stabilise. Since its $\mathrm{pH}$ is high, it is subject to rapid deterioration. The Young Tender Coconut market could be a solution for regional markets but research on the preservation of the fruits will need future efforts, especially in the coating and packaging fields. Concerning coconut water itself, thermal treatment combined with chemical additives are already used by the industry but other technologies such as micro- and ultrafiltration are not yet available on an industrial scale for coconut water. Microfiltration and ultrafiltration can preserve the taste of the fresh coconut water but not the aroma. Ultrafiltration can drastically change the mineral composition of coconut water. Whatever the process, taste, aroma and colour (linked to enzymatic activities) are still difficult to control. Therefore, emerging technologies such as high-pressure, pulsed electric field or ohmic heating should be investigated.

Coconut water extracted from young coconut fruits appears to be a natural healthy beverage and a good alternative to artificial sport drinks. Despite the lack of scientific knowledge on this raw material, the market for it is continuously expanding worldwide.

To satisfy demand, coconut producing countries have been planting Dwarf coconut palm trees for more than 10 years. Green Dwarf in Brazil, King coconut in Sri Lanka, Aromatic Green Dwarf (Nam hon) in Thailand and Chowgat Orange Dwarf in India are some of the most popular cultivars for tendernut consumption around the world. In the future, combined efforts by breeders, biochemists and food processing scientists accompanied by innovative manufacturers will probably increase the quality of young coconut water and give a chance to millions of coconut smallholders to increase the value of their production. 


\section{Acknowledgements}

The authors wish to acknowledge Dr. Olivier Gibert and Mrs Daphne Goodfellow for the English revision of the manuscript.

\section{References}

[1] Pieris W.V.D., L'eau de coco, constituant liquide de l'endosperme de la noix de coco. Note sur la terminologie, Oléagineux 26 (1971) 383-390.

[2] Woodroof J.G., Coconut storage and processing, and minor uses of products of the coconut tree, in: Coconuts: production, processing, products, AVI (Ed.), Westport, U.S.A., 1970.

[3] Batugal P.A., Ramanatha Rao V., Bong C., Promoting multi-purpose uses and competitiveness of the coconut, in: Batugal P.A., Ramanatha Rao V., Bong C.E. (Eds.), IPGRI, Chumphon, Thailand, 1996.

[4] Chandrasekharan V.G., Remany G., Mathew T.M., Exploring trade opportunities for coconut products - An experience from New Delhi, Indian Coconut J. 35 (2004) 22-24.

[5] De Leon S.Y., Delores M.I., Coconut, in: BarrettD.M., Somogyi L.P., Ramaswamy H.S. (Eds.), Processing fruits: science and technology, Boca Raton, Florida, U.S.A., 2005.

[6] Steiner I., Desser A., Coconut water - composition, properties and processing, Ernährung 32 (2008) 513-516.

[7] Dupaigne P., Un jus de fruit peu ordinaire : I'eau de coco, Fruits 26 (1971) 625-627.

[8] Prades A., Dornier D., Diop N., Pain J.P., Coconut water uses, composition and properties: a review, Fruits 67 (2012) 87-107.

[9] Saat M., Singh R., Gamini Sirisinghe R., Nawawi M., Rehydration after exercise with fresh young coconut water, carbohydrateelectrolyte beverage and plain water, J. Physiol. Anthr. Appl. Hum. Sci. 21 (2002) 93-104.

[10] Rao G.V.S., Naik B.J., Giridharan M.P., Stephen R., Balakrishnan P.C., Identification of superior coconut cultivars suitable for tender nut purpose, J. Plant. Crops 36 (2008) 204206.

[11] Anzaldo F.E., Kintinar Q.L., Recto P.M., Velasco R.U., De La CruzF., JacalneA., Coconut water as intravenous fluid, Philipp. J. Coconut Stud. 10 (1985) 31-43.

[12] Gatchalian M.M.,DeLeonS.Y., YanoT.,Comparative profiles of young coconut (Cocos nucifera L.) from fresh and stored nuts, Food Qual. Prefer. 4 (1993) 193-200.

[13] Ranasinghe C.S., Wimalasekara R., Technical guidelines to enhance shelf-life of tender King coconut for the export market, Indian Coconut J. 37 (2006) 17-19.

[14] Thamban C., Subashbabu K., Venugopal R., Muralidharan K., Integrated approach for marketing of minimally processed tender coconuts, Indian Coconut J. 37 (2007) 2-7.

[15] ConsignadoT.O., Tabora P.C., CreenciaR.P., Physico-chemical changes in stored young coconut, Philipp. Agric. 60 (1976) 256-270.

[16] Maciel M.I., Oliveira S.L., Da Silva I.P., Effects of different storage conditions on preservation of coconut (Cocos nucifera) water, J. Food Process. Preserv. 16 (1992) 13-22.

[17] Queiroz R., Aroucha E., Tomaz H., Pontes F., Ferreira R., Analise sensorial da agua-decoco durante o armazenamento dos frutos da cultivar anao verde, Rev. Caatinga 22 (2009) 1-1.

[18] Walter E.H.M., Nascimento M.S., Kuaye A.Y., Efficacy of sodium hypochlorite and peracetic acid in sanitizing green coconuts, Lett. Appl. Microbiol. 49 (2009) 366-371.

[19] Assis J.S. de, Resende J.M., Oliveira e Silva F., Ribeiro dos Santos C., Nunes F., Tecnicas para colheita e pos-colheita do coco verde, Comun. Tec. Embrapa Semi-Arido, 2000, Brazil, $6 \mathrm{p}$.

[20] Jarimopas B., Kuson P., A young-coconutfruit-opening machine, Biosyst. Eng. 98 (2007) 185-191.

[21] Jarimopas B., Ruttanadat N., Development of a young coconut fruit trimming machine, $\mathrm{J}$. Food Eng. 79 (2007) 752-757.

[22] Wazir S.K.S., Technologies on environmentfriendly young tender coconuts, in: Proc. Cocotech Meet., APCC (Ed.), Manila, Philipp., 1997.

[23] Raju V.K, Zahida P.M, Minimal processing of tender coconut, Indian Coconut J. 37 (2007) 22-23.

[24] Viana F.M.P., Uchoa C.N., Vieira I.G.P., Freire F.C.O., Saraiva H.A.O., Mendes F.N.P., Minimal processing, modified atmosphere, chemical products and cooling to control postharvest basal rot of fresh green coconut fruits (Cocos nucifera), Summa Phytopathol. 34 (2008) 326-331.

[25] Sison B.C.J., Disposal of coconut processing waste, Philipp. J. Coconut Stud. 11 (1977) 39-41. 
[26] Pramith P., Oil separation from coconut water by microfiltration method, Rep. No. 62 17, Ntl. Food Res. Inst., Tsukuba, Ibaraki, Japan, 1998.

[27] Joson L., Coconut water utilization, Coconuts Today 7 (1989).

[28] Wickramasinghe R.H., Biomedical and environmental aspects of some coconut-derived products and their production processes in Sri Lanka, Cocos 13 (1998-1999) 8-20.

[29] Del Rosario E.J., Papa G.M., Reyes C.S., Concentration of coconut water by plateand-frame reverse osmosis using composite membranes, Philipp. J. Coconut Stud. 13 (1988) 36-42.

[30] Sanchez P.C., Collado L.S., Gerpacio C.L., Lapitan H., Village level technology of processing coconut water vinegar, Philipp. Agric. (1985) 439-448.

[31] Angeles O.R., Baraquio W.L., Dalmacio I.F., Segubre E.M., Optimization and cost of xanthan gum production from coconut water by Xanthomonas campestris pv. campestris NRRL 1459, 29th Annu. Convention Philipp. Soc. Microbiol., Inc. Laoag, Ilocos Norte, Philipp., 2000.

[32] Prasad V., Reeja S., Development of a selective media for bifidobacteria using coconut water, Indian J. Dairy Sci. 59 (2006) 144-150.

[33] Banzon A.J., Gonzalez O.N., De Leon S.Y., Sanders P.C., Coconut as food, PCRDF, Quezon City, Philipp., 1990.

[34] Alaban C.A., Studies on the optimum conditions for "nata de coco" bacterium or "nata" formation in coconut water, Philipp. Agric. 45 (1962) 490-516.

[35] Budhiono A., Rosidi B., Taher H., Iguchi M., Kinetic aspects of bacterial cellulose formation in nata-de-coco culture system, Carbohydr. Polym. 40 (1999) 137-143.

[36] Hegde S.V., Bio-confectionaries from coconut water, Indian Food Pack. (1996) 50-52.

[37] Iguchi M., Yamanaka S., Budhiono A., Bacterial cellulose: a masterpiece of nature's art, J. Mater. Sci. 35 (2000) 261-270.

[38] Nishi Y., Uryu M., Yamanaka S., Watanabe K., Kitamura N., Iguchi M., Mitsuhashi S., The structure and mechanical properties of sheets prepared from bacterial cellulose. II. Improvement of the mechanical properties of sheets and their applicability to diaphragms of electroacoustic transducers, J. Mater. Sci. 25 (1990) 2997-3001.

[39] Sabularse V., Montalbo M., Hernandez H., Serrano E., Preparation of nata de coco- based carboxymethylcellulose coating and its effect on the post-harvest life of bell pepper (Capsicum annuum I.) fruits, Int. J. Food Sci. Nutr. 60 (2009) 206-218.

[40] Jagannath A., Kalaiselvan A., Manjunatha S.S., Raju P.S., Bawa A.S., The effect of pH, sucrose and ammonium sulphate concentrations on the production of bacterial cellulose (nata-de-coco) by Acetobacter xylinum, World J. Microbiol. Biotechnol. 24 (2008) 2593-2599.

[41] Magda R.R., Coco-softdrink: health beverage from coconut water, Food Mark. Technol. (1992) 22-23.

[42] Montenegro H.M., Coconut oil and its byproducts, J. Am. Oil Chem. Sci. 62 (1985) 259261.

[43] Srivatsa A.N., Sankaran R., Preservation of tender coconut water in polymeric pouches and metal cans, Indian Coconut J. 26 (1/2) (1995) 13.

[44] Chowdhury M.M., Aziz M.G., Uddin M.B., Development of shelf-stable ready-to-serve green coconut water, Biotechnol. 4 (2005) 121-125.

[45] Costa L.M.C., Maia G.A., Costa J.M.C., Figueiredo R.W. de, Souza P.H.M. de, Avaliacao de agua-de-coco obtida por diferentes metodos de conservacao, Cienc. Agrotec. (Brazil) 29 (2005) 1239-1247.

[46] Tzeng E., Chen H.E., Preventing nonenzymatic browning in coconut water during sterilization, Food Sci. (Taiwan) 25 (1998) 304-313.

[47] Gabriel A.A., Cruz K.G.S., Guzman J.A.D.D., Thermal death times of Escherichia coli in young coconut endosperm beverage, J. Food Process. Preserv. 33 (2009) 136-144.

[48] Fontan R. da C.I., Santos L.S., Bonomo R.C.F., LemosA.R., Ribeiro R.P., Veloso C.M., Thermophysical properties of coconut water affected by temperature, J. Food Process Eng. 32 (2009) 382-397.

[49] FoxP.F., Foodenzymology, ElsevierSci.Publ. Ltd., Barking, U.K., 1991.

[50] Campos C.F., Souza P.E.A., Coelho J.V., Gloria M.B.A., Chemical composition, enzyme activity and effect of enzyme inactivation on flavor quality of green coconut water, Philipp. J. Coconut Stud. 20 (1996) 487-500.

[51] Abreu L.F., Faria J. de A.F., Influencia da temperatura e do acido ascorbico sobre a estabilidade fisico-quimica e atividade enzimatica da agua de coco (Cocos nucifera L.) acondicionada assepticamente, Cienc. Tecnol. Aliment. 27 (2007) 226-232. 
[52] Terefe N.S., Yang Y.H., Knoerzer K., Buckow R., Versteeg C., High pressure and thermal inactivation kinetics of polyphenol oxidase and peroxidase in strawberry puree, Innov. Food Sci. Emerg. Technol. 11 (2010) 52-60.

[53] Valderrama P., Marangoni F., Clemente E., Efeito do tratamento térmico sobre a actividade de peroxidase (POD) e polyphenoloxidase (PPO) en maçã (Mallus comunis), Cienc. Tecnol. Aliment. 21 (2001) 321-325.

[54] Lee T.H., Chua L.S., Tan E.T.T., Yeong C., Lim C.C., Ooi S.Y., Aziz R.B., Aziz A.B., bin Sarmidi M.R., Kinetics of thermal inactivation of peroxidases and polyphenol oxidase in pineapple (Ananas comosus), Food Sci. Biotechnol. 18 (2009) 661-666.

[55] Kikuda A.T., Tadini C.C., Fernandes R., Modelo de primeira ordem multicomponente para inativação térmica em processo descontínuo da peroxidase e polifenoloxidase presentes na água de coco verde (Cocos nucifera L.), in: SBCTA (Ed.), XVIII Congr. Bras. Ciênc. Tecnol. Aliment., Porto Alegre, Brazil, 2002.

[56] Murasaki-Aliberti N.D., Silva R.M.C. da, Gut J.A.W., Tadini C.C., Thermal inactivation of polyphenoloxidase and peroxidase in green coconut (Cocos nucifera) water, Int. J. Food Sci. Technol. 44 (2009) 2662-2668.

[57] Matsui K.N., Gut J.A.W., Oliveira P.V., Tadini C.C. de, Inactivation kinetics of polyphenol oxidase and peroxidase in green coconut water by microwave processing, J. Food Eng. 88 (2008) 169-176.

[58] Serrano-Martínez A., Fortea M.l., del Amor F.M., Núñez-Delicado E., Kinetic characterisation and thermal inactivation study of partially purified red pepper (Capsicum annuum L.) peroxidase, Food Chem. 107 (2008) 193199.

[59] Fortea M.I., López-Miranda S., Serrano-Martínez A., Carreño J., Núñez-Delicado E., Kinetic characterisation and thermal inactivation study of polyphenol oxidase and peroxidase from table grape (Crimson Seedless), Food Chem. 113 (2009) 1008-1014.

[60] Anthon G.E., Barrett D.M., Kinetic parameters for the thermal inactivation of qualityrelated enzymes in carrots and potatoes, $\mathrm{J}$. Agric. Food Chem. 50 (2002) 4119-4125.

[61] Matsui K.N., Granado L.M., Oliveira P.V. de, Tadini C.C., Peroxidase and polyphenol oxidase thermal inactivation by microwaves in green coconut water simulated solutions, LWT - Food Sci. Technol. 40 (2007) 852-859.
[62] Rolle R., Good practice for the small-scale production of bottled coconut water, Agricultural and food engineering training and resource materials, FAO, Training guide, Rome, Italy, 2007.

[63] Duarte A.C.P., Coelho M.A.Z., Leite S.G.F., Identification of peroxidase and tyrosinase in green coconut water, Cienc. Tecnol. Aliment. 3 (2002) 266-270.

[64] Satin M., Amorrigi G., Coconut beverage, FAO, Patent GB2318969 depos. 13 May 1998, Rome, Italy, 1998.

[65] Diop N., Caractérisation physico-chimique de l'eau de la noix de coco verte (Cocos nucifera L.) et essais de stabilisation par techniques membranaires, ENSIA-SIARC, Master thesis, Montpellier, France, 2005, $132 \mathrm{p}$.

[66] Jayanti V., Rai P., Dasgupta S., De S., Quantification of flux decline and design of ultrafiltration system for clarification of tender coconut water, J. Food Process Eng. 33 (2010) 128-143.

[67] Carvalho J.M. de, Maia G.A., Figueiredo R.W. de, Brito E.S. de, Rodrigues S., Storage stability of a stimulant coconut water-cashew apple juice beverage, J. Food Process. Preserv. 31 (2007) 178-189.

[68] Carvalho J.M. de, Maia G.A., Figueiredo R.W., Brito E.S. de, Rodrigues S., Development of a blended beverage consisting of coconut water and cashew apple juice containing caffeine, Int. J. Food Sci. Technol. 42 (2007) 1195-1200.

[69] Carvalho J.M. de, Maia G.A., Brito E.S. de, Crisostomo L.A., Rodrigues S., Composicao mineral de bebida mista a base de agua-decoco e suco de caju clarificado, Bol. Cent. Pesqui. Process. Aliment. 24 (2006) 1-12.

[70] Lima A.D, Maia G.A., Sousa P.H.M. de, Prado G.M. do, Rodrigues S., Storage stability of a stimulant coconut water-acerola fruit juice beverage, Int. J. Food Sci. Technol. 44 (2009) 1445-1451.

[71] Silva F.V.G. da, Maia G.A., Sousa P.H.M. de, Lima A.S. da, Costa J.M.C. da, Figueiredo E.A.T. de, Evaluation of the stability of mixed beverage elaborated with coconut water and passion fruit juice, Acta Sci. Technol. 28 (2006) 191-197.

[72] Garcia B., Masa D.B., Rodriguez M.J., Rolle R., Control of pink discoloration in coconut water, Cord 23 (2007) 67-83.

[73] Damar S., Balaban M., Sims C., Continuous dense-phase $\mathrm{CO}_{2}$ processing of a coconut 
water beverage, Int. J. Food Sci. Technol. 44 (2009) 666-673.

[74] Costa L.M.C., Maia G.A., Costa J.M.C. da, Figueiredo R.W. de, Rodrigues M. do C.P., Sousa P.H.M. de, Pinheiro A.M., Qualidade e vida de prateleira da agua de coco obtida pelo processo de enchimento a quente, Rev. Bras. Armazenamento 31 (2006) 95-102.

[75] Magalhaes M.P., Gomes F. dos S., Modesta R.C.D., Matta V.M. da, Cabral L.M.C., Conservação de ágna de coco verde per filtração con membrana, Ciênc. Tecnol. Aliment. 25 (2005) 72-77.

[76] Reddy K.D., Das M., Das S.K., Nonthermal sterilization of green coconut water for packaging, J. Food Qual. 30 (2007) 466-480.

[77] Reddy K.V., Das M., Das S.K., Filtration resistances in non-thermal sterilization of green coconut water, J. Food Eng. 69 (2005) 381385.

[78] Naozuka J., Murasaki N.C., Tadini C.C., Oliveira P.V. de, Estudo da Influência de Processos de Conservação na Distribuição de Espécies Elementares em Água de Coco, in: SBCTA (Ed.), XIX Congr. Bras. Ciênc. Tecnol. Aliment., Recife, Brazil, 2004.

[79] Luvielmo M. de M., Vasconcelos M.A.M. de, Marques G.R., Silva R.P.G. da, Damasio M.H., Influencia do processamento nas caracteristicas sensoriais da agua-de-coco, Bol. Cent. Pesqui. Process. Aliment. 22 (2004) 253-270.

[80] De Sousa R.A., Silva J.C., Baccan N., Cadore S., Determination of metals in bottled coconut water using an inductively coupled plasma optical emission spectrometer, J. Food Compos. Anal. 18 (2005) 399-408.

[81] Abreu L.F., Araujo A.V., Araujo E.A.F., El-Ouar A.A., Neumann D., Morais M.M., Silva
M.A.A.P. da, Perfil sensorial e aceitabilidade de amostras de agua-de-coco obtidas por diferentes processos de fabricacao, Bol. Cent. Pesqui. Process. Aliment. 23 (2005) 397-412.

[82] Pinheiro A.M., Machado P.H., Costa J.M.C. da, Maia G.A., Fernandes A.G., Rodrigues M. do C.P., Herreyra Hernandez F.F., Caracterizaçao química, físico-química, microbiologica e sensorial de diferentes marcas de agua de coco pelo processo asseptico, Rev. Ciênc. Agron. 36 (2005) 209-214.

[83] Fortes E.P., Lima A. de, Cronemberger M.G. de O., Crispim L. da S., Qualidade físico-química e microbiologica das aguas-de-coco envasadas, comercializadas em Teresina, Piaui, Rev. Hig. Aliment. 20 (2006) 87-90.

[84] Nunes B.N., Cruz A.G., Faria J.A.F., Sant'Ana A.S., Silva R., Moura M.R.L., A survey on the sanitary condition of commercial foods of plant origin sold in Brazil, Food Control 21 (2010) 50-54.

[85] Walter E.H.M., Kabuki D.Y., Esper L.M.R., Sant'Ana A.S., Kuaye A.Y., Modelling the growth of Listeria monocytogenes in fresh green coconut (Cocos nucifera L.) water, Food Microbiol. 26 (2009) 653-657.

[86] Gobin A., Falade K., Akingbala J., Effect of packaging on physical, chemical and sensory attributes of coconut water during storage, $\mathrm{J}$. Food Agric. Environ. 7 (2009) 62-65.

[87] Cesario M.C. de P., Andrade M.V.V., Coelho A.A., Pereira S.M.de F., Martins M.L.L., Henry F. da C., Avaliação físico-química da água de coco, Hig. Aliment. 23 (2009) 39-42.

[88] Sabapathy S.N., Bawa A.S., Standards for packed and preserved tender coconut water, Indian Coconut J. 38 (2007) 2-8.

\section{Conservación y transformación del agua de coco: una síntesis.}

Resumen - El producto. El agua de coco (Cocos nucifera L.) es un refresco tropical, cuyas propiedades funcionales naturales interesan hoy a los industriales. Conservación. Este líquido procede de los cocos inmaduros, cuya cosecha y almacenamiento son delicados. No obstante, algunos estudios llevados a cabo sobre todo en Asia, tienden a demostrar que podrían existir tratamientos posteriores a la cosecha para prolongar la duración de vida de los cocos inmaduros. Transformación. Lógicamente, el agua de coco extraída del fruto es más fácil de manipular y transportar, pero su composición hace que sea particularmente sensible a las degradaciones biológicas y químicas. Hoy en día, en la industria, se emplean tratamientos térmicos combinados con el uso de aditivos, sin embargo, otros tratamientos, tales como la micro o la ultrafiltración, aún no están disponibles para este producto. Independientemente del proceso de estabilización empleado, sigue siendo difícil preservar el sabor y el aroma originales del agua del coco. Discusión. En la presente síntesis, por primera vez, se presentan los estudios sobre el agua de coco, desde los más antiguos hasta los más recientes. Éstos dan lugar a proponer ideas para mejorar nuestro conocimiento acerca de este singular zumo de frutas tropical.

Francia / Cocos nucifera / coco / agua de coco / etapas de desarrollo de la planta / maduración / calidad / almacenamiento / preservación / aptitud para la conservación / procesamiento 